\title{
Quantification by computerized morphometry of tissue levels of sulfomucins and sialomucins in diversion colitis in rats ${ }^{1}$
}

\author{
Quantificação por morfometria computadorizada dos níveis teciduais de sulfomucinas e \\ sialomucinas na colite de exclusão em ratos
}

\author{
Carlos Augusto Real Martinez ${ }^{\mathrm{I}}$, Ronaldo Nonose ${ }^{\mathrm{II}}$, Ana Paula Pimentel Spadari ${ }^{\mathrm{III}}$, Felipe Rodrigues Máximo ${ }^{\mathrm{III}}$, Denise Gonçalves \\ Priolli $^{\mathrm{IV}}$, José Aires Pereirav ${ }^{\mathrm{V}}$, Nelson Fontana Margarido ${ }^{\mathrm{I}}$

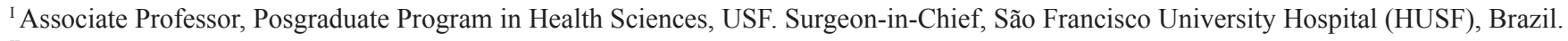 \\ ${ }^{\text {II }}$ Fellow Master Degree, Posgraduate Program in Health Sciences, USF, Bragança Paulista, São Paulo, Brazil. \\ III Graduate student, Medical School, Scholarship holder of the Scientific Initiation Program (PROBAIC), USF, São Paulo, Brazil. \\ ${ }^{I V}$ Associate Professor, Posgraduate Program in Health Sciences, USF, Bragança Paulista, São Paulo, Brazil. \\ ${ }^{v}$ Assistant Professor, Division of Pathology, USF, Bragança Paulista, São Paulo, Brazil.

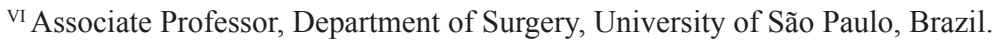

\begin{abstract}
Purpose: To quantify the intensity of sulfomucin and sialomucin expression in the colon mucosa, by means of computer-assisted image processing, comparing segments with and without fecal stream and correlating with the duration of fecal transit exclusion. Methods: Forty-five Wistar rats were subjected to diversion of the fecal stream in the left colon by means of constructing a proximal colostomy and distal mucosal fistula. They were distributed randomly into three experimental groups of 15 animals, of which 10 were subjected to colon diversion (experimental subgroup) and five were only subjected to laparotomy, without colon diversion (control subgroup). The three experimental groups were formed according to the sacrifice date, which was to be performed six weeks after the surgical procedure (Group A), 12 weeks (Group B) and 18 weeks (Group C). The sulfomucin and sialomucin expression in the colon mucosa was evaluated using the histochemical technique of high iron diamine-alcian blue (HID-AB). The tissue expression was quantified for each animal, in the segments with and without fecal stream, at a location where there were four complete contiguous crypts in two random fields, with the aid of the computer-assisted image analysis software. The final value was taken to be the mean reading from the two fields selected, in the segments with and without fecal stream. To compare the expressions of the two mucin subtypes in the segments with and without fecal stream, the paired Student $t$ test was used. To analyze variance according to duration of exclusion, ANOVA with the Newman-Keuls post-test was used, setting the significance level at $5 \%(p<0.05)$. Results: There were significant reductions in tissue sulfomucin and sialomucin content in the colon without fecal stream, independent of the duration of exclusion considered. There was increased tissue sulfomucin content and decreased tissue sialomucin in the segments without fecal stream, with increasing duration of exclusion. Conclusions: Diversion of the fecal transit decreased the tissue sulfomucin and sialomucin content in the segments without fecal stream. Notwithstanding the reduction in the levels of both subtypes of acid mucin in the segments without fecal stream, there was increased tissue sulfomucin content and decreased tissue sialomucin with increasing duration of intestinal diversion.
\end{abstract}

Key words: Colon. Colitis. Colostomy. Mucins. Sialomucins. Image Processing, Computer Assisted. Rats.

\section{RESUMO}

Objetivo: Quantificar, por meio de processamento de imagem assistida por computador, a intensidade de expressão de sulfomucinas e sialomucinas na mucosa cólica comparando segmentos com e sem trânsito e relacionando-a ao tempo de exclusão de trânsito fecal. Métodos: Quarenta e cinco ratos Wistar machos foram submetidos à derivação do trânsito no cólon esquerdo pela confecção de colostomia proximal e fístula mucosa distal. Foram divididos de forma randomizada em três grupos experimentais de 15 animais, nos quais 10 foram submetidos à derivação do trânsito cólico (subgrupo experimental) e cinco somente a laparotomia exploradora sem desvio do trânsito fecal (subgrupo controle). Os três grupos experimentais foram formados segundo o sacrifício ter sido realizado em seis (grupo A), 12 (Grupo B) e 18 semanas (Grupo C). A avaliação da expressão de sulfomucinas e sialomucinas na mucosa cólica foi realizada pela técnica histoquímica da diamina de ferro alto alcian-blue (HID-AB). A quantificação da expressão tecidual foi determinada, para cada animal, nos segmentos com e sem trânsito, em local onde existiam quatro criptas contíguas e íntegras em dois campos aleatórios com auxílio de programa de análise de imagem assistida por computador. Adotou-se como valor final a média das leituras dos dois campos selecionados, nos segmentos providos e desprovidos de trânsito fecal. Na comparação entre a expressão dos dois subtipos de mucinas nos segmentos com e sem trânsito fecal utilizou-se o teste t de Student pareado. Para análise de variância segundo o tempo de exclusão 
utilizou-se o teste de ANOVA com o pós-teste de Newmann-Keuls, estabelecendo-se nível de significância de 5\% (p<0,05). Resultados: Houve redução significante no conteúdo tecidual de sulfomucinas e sialomucinas no cólon desprovido de trânsito fecal, independente do tempo de exclusão considerado. Houve aumento no conteúdo tecidual de sulfomucinas e diminuição de sialomucinas nos segmentos exclusos de trânsito fecal com o progredir do tempo de exclusão. Conclusões: A derivação do trânsito fecal diminui o conteúdo tecidual de sulfomucinas e sialomucinas nos segmentos desprovidos de trânsito fecal. Não obstante a redução do conteúdo de ambos os subtipos de mucinas ácidas nos segmentos desprovidos de trânsito fecal existe aumento no conteúdo tecidual de sulfomucinas e redução no conteúdo de sialomucinas com o progredir do tempo de derivação intestinal.

Descritores: Cólon. Colite. Colostomia. Mucinas. Sialomucinas. Processamento de Imagem Assistida por Computador. Ratos.

${ }^{1}$ Research performed at Posgraduate Program in Health Sciences, São Francisco University (USF), Bragança Paulista, São Paulo, Brazil.

\section{Introduction}

Glotzer et al. ${ }^{1}$ described the development of an inflammatory process in the mucosa of colon segments without fecal stream for the first time. They gave the name "diversion colitis" to this new form of intestinal inflammatory disease. Since this initial description, studies have been demonstrating that the etiopathogenesis of diversion colitis is probably related to intraluminal deficiency of short-chain fatty acids (SCFAs), which are the main energy substrate for colon epithelial cells ${ }^{2,3}$.

There are controversies regarding histopathological analyses on colon mucosal segments that have been excluded from the fecal stream. This demonstrates that the disease follows its course with a variety of changes and that there is no characteristic pattern $^{2-4}$. The most common finds include epithelial erosions or ulcerations, decreased length or modified architecture of the colon crypts, inflammatory infiltrate, diffuse nodular lymphoid hyperplasia, vascular congestion of the submucosa and depletion of the number of caliciform cells, with consequent modifications to the production of mucins by the mucous epithelium ${ }^{2-4}$.

The mucous layer covering the colon epithelium is the first line of defense against invasion of the intestinal wall by bacteria and antigen that are present in the intestinal lumen ${ }^{5}$. Most of the protective effect provided by the mucous layer relates to the presence of mucins, which are the predominant glycoproteins in the chemical composition of this layer ${ }^{6,8}$. Briefly, the mucosa of the digestive tract produces two main types of mucins, represented by neutral and acid mucins ${ }^{7}$. Acid mucins are composed of sulfomucins and sialomucins ${ }^{6}$. Neutral mucins are expressed in greater quantities in the more cranial portions of the digestive tract and, going towards the colon, the predominant tissue expression changes to acid mucins.

It has already been demonstrated that the capacity of the colon epithelium for mucin synthesis depends on adequate supply of SCFAs ${ }^{7}$. Recent studies have shown the importance of maintaining the supply of SCFAs, particularly butyrate, in order to have adequate gene expression relating to mucin formation ${ }^{8,9}$.

The proportions between sulfomucins and sialomucins is usually constant in the mucosa of normal colon tissue, but may undergo changes in various illnesses ${ }^{6,10}$. In has already been demonstrated that there is a notable increase in the tissue expression of sialomucins in the dysplastic colon mucosa of patients with ulcerative colitis ${ }^{11}$. Some authors consider that this change in the inflamed epithelium might precede the development of neoplasia, thus making it useful to investigate the tissue expression of mucins, in order to evaluate the risk of malignant transformation ${ }^{12}$. This evidence is corroborated by the results from experimental studies that demonstrated increased sialomucin production in colon mucosal cells in segments without fecal stream that were used to reconstruct the urinary transit ${ }^{13}$. Since patients who undergo ureterosigmoid diversion present a greater risk of developing neoplasia, it is possible that modifications to the tissue expression of mucins might also be considered in such patients to be a potential histological marker capable of predicting the risk of developing neoplasia ${ }^{14,15}$.

Despite the clinical, endoscopic and histopathological similarities between ulcerative colitis and diversion colitis, the appearance of neoplasia in segments excluded from the fecal stream in patients undergoing intestinal diversion due to diseases other than inflammatory intestinal disease is exceptional. It is possible that the tissue expression of acid mucins in cases of diversion colitis occurs differently from what happens in patients with ulcerative colitis.

To the best of our knowledge, only a single study has evaluated the changes to acid mucin expression in colon segments without fecal stream ${ }^{6}$. In that study, modifications relating both to location and to tissue content of acid mucins were found, with decreased production of sialomucins, i.e. the inverse of what is seen in ulcerative colitis ${ }^{6}$. However, in that study, the tissue quantification of acid mucin content was determined subjectively, and no analysis method that might have allowed precise determination of its real concentration in the colon epithelium was used $^{6}$.

With the advent of computer-assisted image analysis software, it has become possible to objectively quantify the tissue expression of various proteins, stained using histochemical or immunohistochemical techniques ${ }^{16,17}$. With this method, it has become possible to quantify the expression of sulfomucins and sialomucins in the colon mucosa more precisely, thereby observing changes in total acid mucin content and the influence of the duration of exclusion, by comparing segments with and without fecal stream. Through the use of an objective method for tissue quantification, it might be possible to confirm the particular characteristics of the expression of acid mucin subtypes in colon segments without intestinal transit.

The aims of the present study were to quantify the tissue sulfomucin and sialomucin content in the colon mucosa, by means of computerized morphometry, comparing segments with and without fecal stream, and to investigate the relationship with the duration of colon exclusion. 


\section{Methods}

This study was conducted in accordance with Federal Law No. 11,794 (10/08/2008) and the guidelines of the Brazilian College for Animal Experimentation (COBEA). It received approval from the Research Ethics Committee for Animal Research of São Francisco University, Bragança Paulista, São Paulo, Brazil.

Forty-five male SPF Wistar rats (Rattus norvegicus albinus) from the Multidisciplinary Center for Biological Investigation of the State University of Campinas (CEMIBUNICAMP) were used. They weighed between 300 and 380 grams and their mean age was four months. They were distributed randomly into three experimental groups of 15 animals, of which 10 were subjected to colon diversion (experimental subgroup) and five were only subjected to laparotomy, without colon diversion (control subgroup). The three experimental groups were formed according to the sacrifice date, which was to be performed six weeks after the surgical procedure (Group A), 12 weeks (Group B) and 18 weeks (Group C).

On the day before the surgical procedure, the animals were kept in individual cages, under fasting conditions (except for water), for 24 hours. After being individually identified, they were weighed and anesthetized using 2\% xylazine hydrochloride plus ketamine hydrochloride, at a dosage of $0.1 \mathrm{ml} / 100 \mathrm{~g}$, administered intramuscularly. The abdominal cavity was accessed by a median longitudinal incision of three centimeters in length, and the left colon was identified. With the aid of a pachymeter and after ligature of the vessels of the marginal arcade, the left colon was sectioned four centimeters above the proximal extremity of Peyer's patch. After removing any fecal content that might have been present, the proximal segment of the left colon was brought to the exterior as an end colostomy, attached to the skin. The distal segment of the sectioned colon was catheterized using a $12 \mathrm{~F}$ polyvinyl probe and was irrigated with $0.9 \%$ physiological solution until the effluent draining out through the animal's anus no longer included any fecal material. After this irrigation, the catheter was removed and the distal colon was brought to the exterior as a distal mucous fistula on the lower left lateral face of the abdominal wall. The abdominal wall was closed as two sutured layers (peritoneum and aponeurosis). After concluding the operation, the animals were housed in individual cages and were allowed to have water and standard feed, once they had recovered movement. They remained in a climate-controlled environment, with temperature and lighting regulation, and they were weighed every week. No additional care was provided with regard to the operative wound and the stoma that had been constructed.

For sacrificing, the animals were kept fasting for 24 hours, except for water. They were again anesthetized, using the same technique as described earlier, and underwent median laparotomy to remove all the colon segments with and without fecal transit. To ensure uniformity in the histological analysis, the specimens (measuring three centimeters in length) were always collected from a predetermined location, one centimeter from the internal attachment of the stoma on the parietal peritoneum. The resected colon segments with transit from each animal were taken as the control group for the alterations to the colon without transit, in order to avoid the influence of weight gain on any histological changes that might be found. The sacrifice was carried out by means of a lethal dose of anesthetic drug.

The colon segments that were removed were opened up longitudinally along the antimesocolic edge. They were then laid out and pinned on a flat cork surface with the mucous surface uppermost. The mounted specimens were then stored in flasks containing $10 \%$ formaldehyde solution for 72 hours. Following this, the material was embedded in paraffin blocks and longitudinal sections of $4 \mu \mathrm{m}$ in thickness were cut perpendicularly to the mucous surface, in order to carry out histopathological and morphometric analyses. Two slides from each colon segment in each experimental group (colon with and without fecal stream), along with slides from the control subgroup animals, were stained using the hematoxylin-eosin technique. The diagnosis and degree of inflammation of the exclusion colitis were established in accordance with a scale that had previously been validated (Chart 1$)^{18}$.

CHART 1 - Grading scale for inflammation score

\begin{tabular}{|c|c|c|}
\hline Degree of inflammation & Score & Histopathological characteristics \\
\hline Absent & 0 & Without neutrophil infiltration into tissue \\
\hline Mild & 3 & $\begin{array}{l}\text { Neutrophil infiltration }<50 \% \text { of crypts } \\
\text { or } \\
\text { Neutrophil infiltration }<50 \% \text { of fields } \\
\text { or } \\
\text { Absence of erosion or ulcers }\end{array}$ \\
\hline Moderate & 6 & $\begin{array}{l}\text { Neutrophil infiltration } \geq 50 \% \text { of crypts } \\
\text { or } \\
\text { Neutrophil infiltration } \geq 50 \% \text { of fields } \\
\text { or } \\
\text { Absence of erosion or ulcers }\end{array}$ \\
\hline Severe & 8 & Presence of erosion or ulcers \\
\hline
\end{tabular}

Based on Grupta et al. ${ }^{19}$ - Mount Sinai Hospital (modified) 
To identify the acid mucins (sulfomucins and sialomucins), the slides were stained using the histochemical technique of high iron diamine-alcian blue (HID-AB), in accordance with the standardized methodology ${ }^{14}$. In summary, the slides were deparaffinized in two successive xylol baths for 10 minutes, given an alcohol rinse in three successive baths of pure alcohol and then hydrated in running water for five minutes. After this step, they were washed in three successive baths of distilled water and were then exposed to high iron diamine (HID) for six hours. The HID solution was made up of $120 \mathrm{mg}$ de NN-dimethyl-metaphenylenediamine-dihydrochloride, $20 \mathrm{mg}$ de NN-dimethylparaphenylenediamine-dihydrochloride, $50 \mathrm{ml}$ of distilled water and $1.4 \mathrm{ml}$ of a recently prepared solution of $60 \%$ ferric chloride. At the end of the staining with HID, the sections were washed in running water for five minutes and then in three successive baths of distilled water. Following this, they were exposed to the staining agent alcian blue (AB) for 10 minutes and then washed in running water for five minutes and three successive baths of distilled water. The $1 \%$ AB staining medium was prepared in acetic acid ( $\mathrm{pH} 2.5)$. At the end of this step, the slides were counterstained with neutral red for eight minutes and again washed in running water. They were then dehydrated in three successive baths of pure alcohol and diaphanized in three baths of xylol, and cover slips were mounted using resin. Through the HID-AB technique, it was seen that the sulfomucins stained brown while the sialomucins stained blue.

The slides were read under an ordinary optical microscope at a final magnification of 200x. The histological abnormalities were analyzed with regard to the presence of colitis, in accordance with the proposed grading scale, by a pathologist experienced in diseases of the digestive tract who was unaware of the origin of the material or the objectives of the study.

The expression of sulfomucins and sialomucins was quantified by means of computer-assisted image processing and this was always done in a field in which at least four complete contiguous colon crypts were present. The image selected was captured using a video camera coupled to the optical microscope. This image was then processed and analyzed using the NISElements software, which was installed in a microcomputer with a high image processing capacity. By means of colored histograms, the software determined the color intensity of each area selected for measurement and transformed the color chosen into a percentage numerical expression, for each field of view selected (Figure 1). The final values taken for the segments with and without intestinal transit were the mean values found from evaluating three different fields.

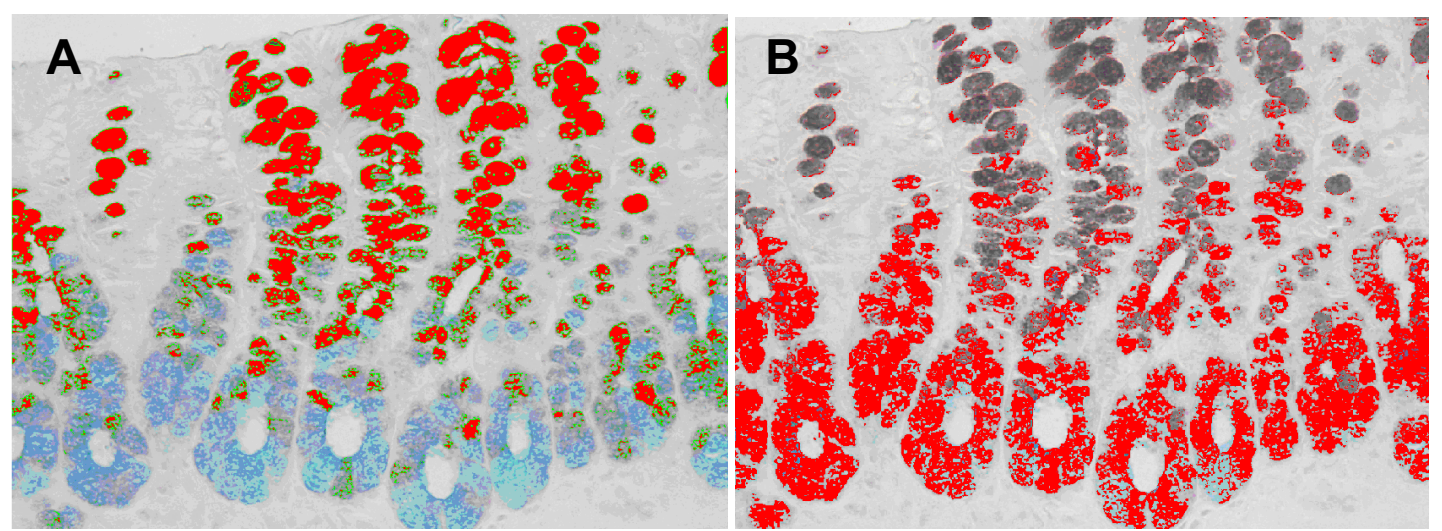

FIGURE 1 - A. Quantification of sulfomucins by means of computerized morphometry in a segment with transit after fecal exclusion for 12 weeks. B. Quantification of sialomucins in the same field of view (HID-AB 200x)

The statistical analysis on the results obtained was performed by taking a significance level of $5 \%(p \leq 0.05)$. The data obtained from each colon segment analyzed, in each experimental group, were expressed as mean values with the respective standard deviation and were analyzed using the SPSS for Windows statistical software (version 13.0). To compare inflammation scores between the control and experimental group animals (segments with and without fecal transit), the MannWhitney test was used. To compare the tissue sulfomucin and sialomucin content between the segments with and without fecal stream, Student's t test was used. To analyze the variance in sulfomucin and sialomucin expression between the different experimental groups, the ANOVA test was used and, when the result was significant, the Newman-Keuls post-test was used.

\section{Results}

Figure 2 shows that the inflammation grading score was greater in the segments without fecal stream than in the segments with transit or in the animals of the control subgroups, independent of the duration of exclusion. These values became significant after 12 and 18 weeks of intestinal exclusion. 


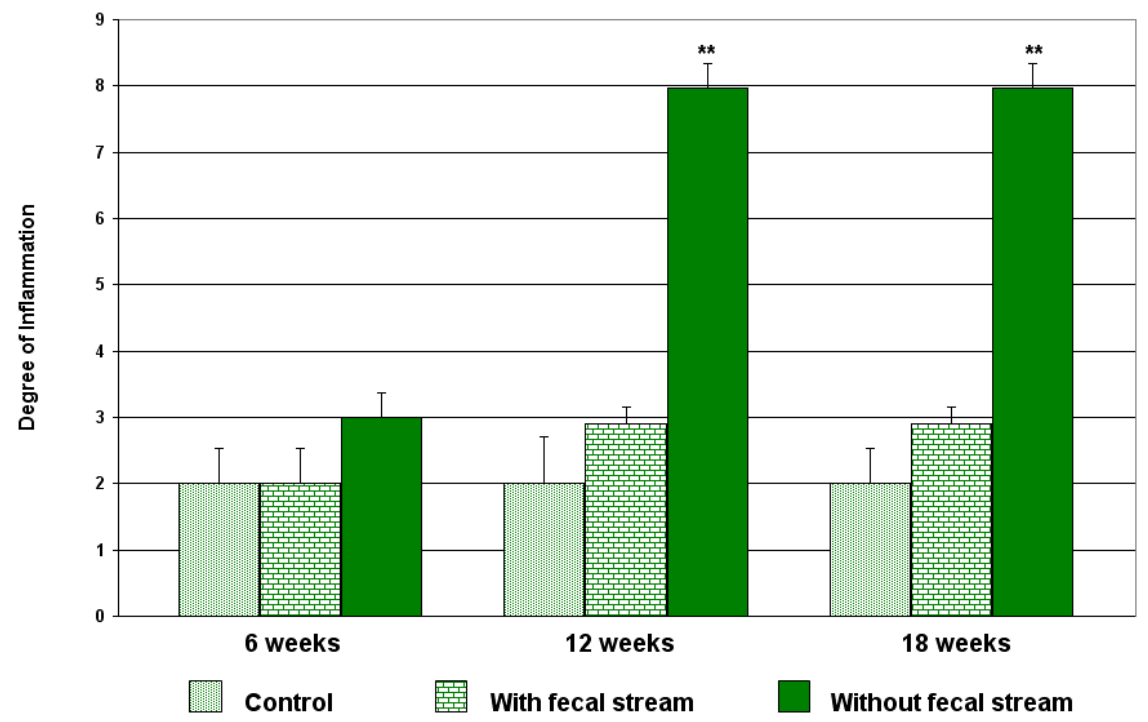

FIGURE 2 - Inflammation grading score in the control groups and experimental groups (segments with and without fecal stream) after the different durations of exclusion proposed $(* *=$ distal $>$ control and proximal). Mann-Whitney test

From analysis on the acid mucin expression pattern across the colon crypts in the segments with fecal stream, it was found that the sialomucins were concentrated in the deeper portions of the colon crypts, while the sulfomucins were in the upper portions.
In the segments without fecal stream, the sulfomucins became present throughout the colon crypts, and there was a marked reduction in sialomucin expression, independent of the duration of fecal exclusion (Figure 3).
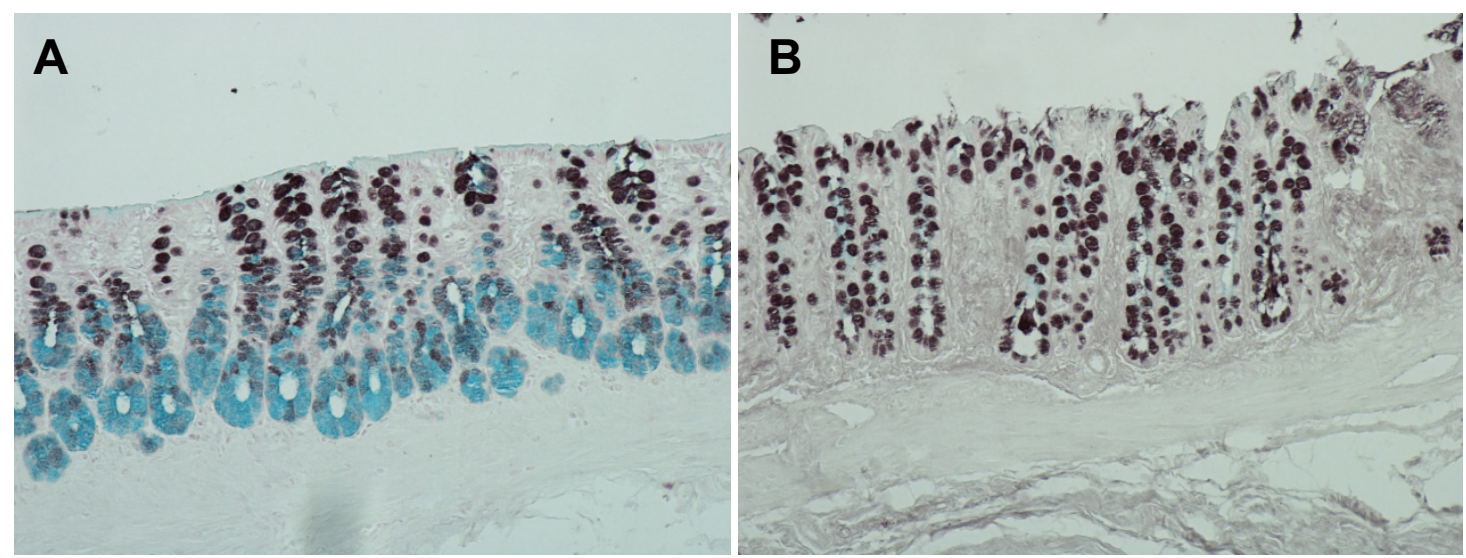

FIGURE 3 - Animals subjected to exclusion of fecal stream for 18 weeks (Group C). A. Sulfomucin and sialomucin expression in the colon crypts in a segment with fecal transit. B. Sulfomucin and sialomucin expression in the colon crypts in a segment without fecal stream (HID-AB, 100x)

Figure 4 shows the means and respective standard deviations of the sulfomucin percentages quantified in the animals of the control and experimental subgroups (with and without fecal stream), for the different durations of exclusion. A marked reduction in tissue sulfomucin content was seen in the segments without fecal stream, independent of the duration of exclusion considered. 


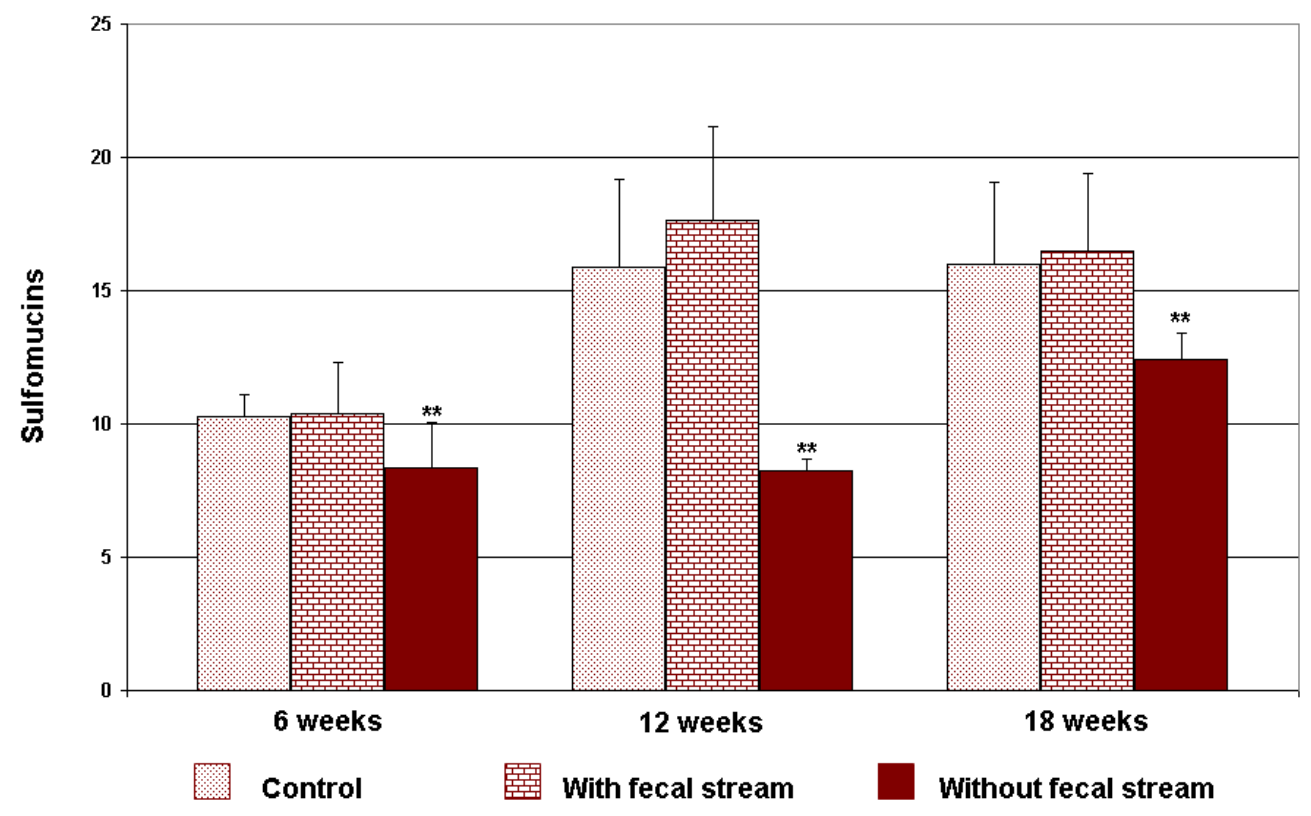

FIGURE 4 - Quantification of sulfomucin expression in the control groups and experimental groups (segments with and without fecal stream) after the different durations of exclusion proposed $(* *=$ distal $<$ control and proximal). Student's t test

Figure 5 shows the means and respective standard deviations of the sialomucin percentages quantified in the animals of the control and experimental subgroups (segments with and without fecal stream), for the different durations of exclusion. A marked reduction in tissue sialomucin content was seen in the segments without fecal stream, independent of the duration of exclusion considered.

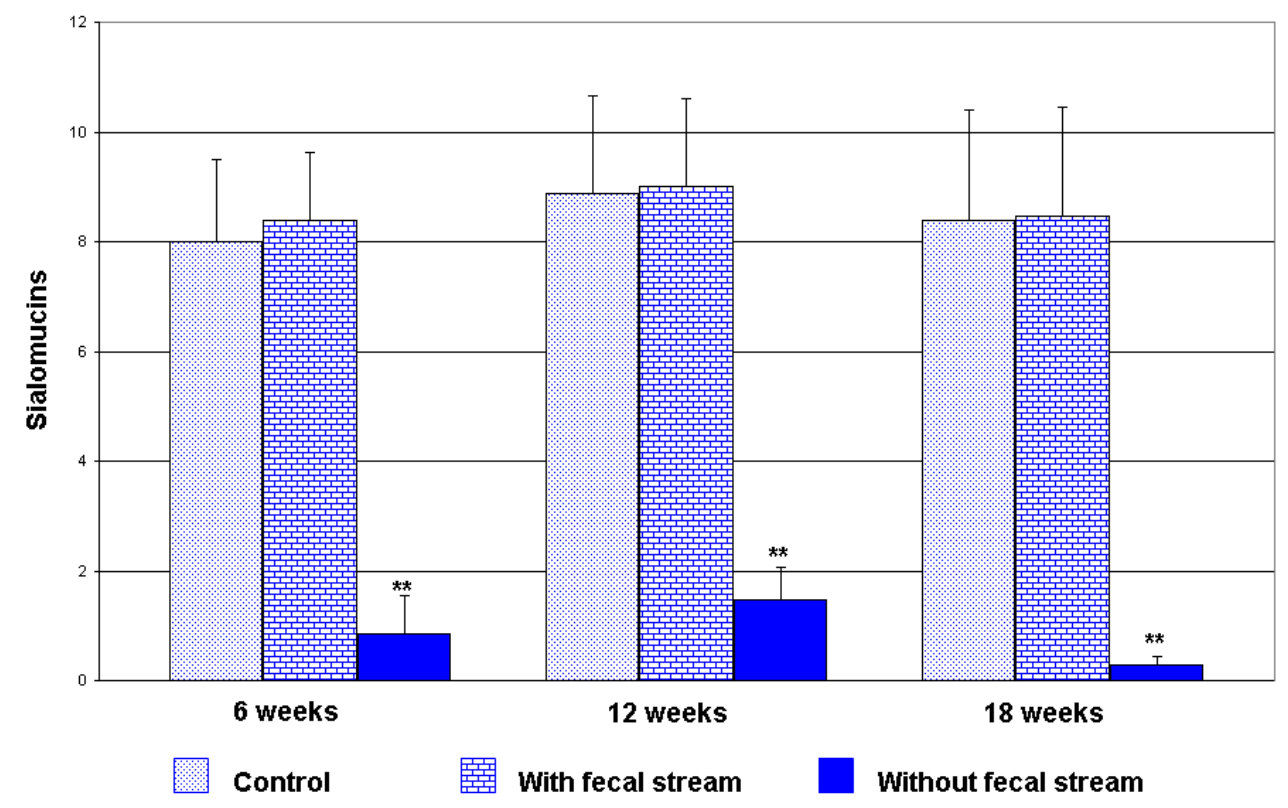

FIGURE 5 - Quantification of sialomucin expression in the control groups and experimental groups (segments with and without fecal stream) after the different durations of exclusion proposed $(* *=$ distal $<$ control and proximal). Student's t test 
Table 1 shows the means and respective standard deviations of the variations in sulfomucin and sialomucin percentages quantified in the colons with and without fecal stream, for the different durations of exclusion. It can be seen that the sulfomucin content in the excluded colon had increased significantly after 18 weeks of intestinal exclusion. Inversely, the tissue sialomucin content presented a significant reduction after 18 weeks of fecal exclusion.

TABLE 1 - Variation in mean percentages of sulfomucin and sialomucin content measured in segments without fecal stream, in relation to the different durations of exclusion

\begin{tabular}{|c|c|c|c|c|c|}
\hline & \multicolumn{3}{|c|}{ Colon without fecal stream } & \multirow[b]{3}{*}{ NK } & \multirow[b]{3}{*}{$\mathbf{p}$} \\
\hline & \multicolumn{3}{|c|}{ Mean \pm SD (\%) } & & \\
\hline & 6 weeks & 12 weeks & 18 weeks & & \\
\hline Sulfomucins & $8.349 \pm 1.69$ & $8.224 \pm 0.47$ & $12.43 \pm 0.98$ & $\begin{array}{l}A \times B \\
A \times C \\
B \times C\end{array}$ & $\begin{array}{l}>0.05 \\
<0.01 * \\
<0.01 *\end{array}$ \\
\hline Sialomucins & $0.853 \pm 0.31$ & $1.47 \pm 0.68$ & $0.279 \pm 0.17$ & $\begin{array}{l}A \times B \\
A \times C \\
B \times C\end{array}$ & $\begin{array}{l}>0.05 \\
<0.05 \\
<0.01 *\end{array}$ \\
\hline
\end{tabular}

\section{Discussion}

The main function of mucus is to serve as protection for the epithelial cells of the intestinal mucosa, against aggression caused by enzymes, antigens and bacteria that are present in the intestinal lumen ${ }^{9,14}$. The protective effect of the mucus is related to the presence of mucins, which are predominantly glycoproteins in their composition. In addition to providing mechanical protection, they present bactericide properties ${ }^{7,8}$. Breakage of the protective barrier or mucus, as occurs in inflammatory intestinal diseases, allows invasion of bacteria through the epithelial surface ${ }^{7,8,19}$.

The mucin molecules produced along the whole length of the digestive tube are composed of glycid and protein fractions. Regarding the protein fraction, mucins of the subtype MUC2 are the ones most often found, although the subtypes MUC1, MUC3 and MUC4 may also be expressed in smaller quantities ${ }^{9}$. Regarding the glycid fraction, mucins belong to two main histochemical groups: neutral and acid mucins $\mathrm{s}^{20,21}$. The glycid fraction of neutral mucins is rich in glycogen and these mucins are usually found in the stomach and small intestine. However, they may also be identified at lower concentrations in the large intestine, particularly in the cecum and proximal colon ${ }^{21}$. Acid mucins are represented by two main subtypes: sulfomucins, which are rich in sulfate radicals in their glycid fraction; and sialomucins, which are rich in sialic acid. Acid mucins are expressed along the whole length of the colon mucosa, but with greater predominance in the mucosa of the colon and rectum ${ }^{21}$. Both in humans and in rats, sulfomucins differ from sialomucins in terms of their quantities and locations in the colon crypts, considering the different segments of the large intestine $^{21,22}$. In the present study, with the aim of ensuring that the analysis on the expression pattern and tissue content was always performed on the same segment of the colon, the colon fragments were always taken from a preestablished location.
The capacity for mucin synthesis shown by the caliciform cells of the colon mucosa depends on an adequate supply of energy substrate $^{9,10,22}$. SCFAs, which are produced from fermentation of dietary fibers caused by anaerobic bacteria in the intestinal lumen, represent $90 \%$ of all the energy supplies used by the epithelial cells of the colon mucosa $\mathrm{a}^{23}$. SCFAs modulate both cell proliferation and local immunity and they have an important role in relation to the integrity of the colon epithelium ${ }^{24,25}$. Reductions in the supply of SCFAs, as occurs during intestinal diversion operations, are accompanied by morphological and functional changes, thereby causing reductions in protein synthesis capacity ${ }^{26}$. The mechanisms through which shortages of SCFAs lead to lower capacity for mucin production are still not completely clear $^{9,27}$. Studies have shown that intestinal diversion reduces the quantities of dietary fiber and modifies the bacterial populations in the segment excluded and it decreases the production of SCFAs, thereby causing a state of nutritional deficiency for the cells of the colon mucosa ${ }^{28-30}$. This nutritional deficiency reduces the mucin synthesis capacity of these cells ${ }^{8}$. Reinforcing this evidence, studies have shown that administration of SCFA enemas increases the mucin synthesis capacity of the colon mucosa cells, while administration of enemas containing sodium bromo-octanoate (a powerful inhibitor of SCFA metabolization) completely blocks mucin synthesis and causes the appearance of colitis ${ }^{8,29}$. Recent research has also demonstrated that shortages of SCFAs greatly reduces the expression of the MUC-2 gene, which is the main agent responsible for transcription of the protein fraction of colon mucins ${ }^{9,10}$. The MUC-1, MUC-3 and MUC- 4 genes also present lower expression in the absence of butyrate, thus giving rise to an even greater decrease in glycoprotein production $^{9,10}$.

Abnormalities of mucin secretion, composition and 
distribution pattern in the intestinal epithelium have been demonstrated in various diseases that affect the colon ${ }^{11-13}$. Studies using biochemical, histochemical and immunohistochemical techniques have demonstrated that, in the different forms of colitis, abnormalities occur not only in the tissue content but also in the expression pattern of mucins along the crypts of the colon mucosa $a^{21,22,30-33}$. These findings have made it attractive to hypothesize that the etiopathogenesis of ulcerative colitis might be related to changes in mucin production in individuals with predisposing factors, or to changes caused by intraluminal factors ${ }^{8}$.

It has been shown that deviation of the fecal transit in rats causes histological changes that are identical to those that occur in the human colon. Thus, rats are the animals most used as experimental models for exclusion colitis ${ }^{5,6,9,10}$. Such studies have demonstrated reduced thickness of the colon crypts, epithelial ulcerations, vascular congestion of the submucosa, greater neutrophil infiltration, changes to caliciform cell populations and histological abnormalities. These changes make it possible to diagnose diversion colitis ${ }^{5,6,37}$. In the present study, we used an experimental model that had been described previously, in which intestinal diversion was performed by means of constructing a proximal terminal colostomy, with diversion back into the distal segment through a distal fistula in the mucosa ${ }^{37}$. This experimental model was chosen because we believed that intestinal diversion through the use of loop colostomies would not ensure complete exclusion of the fecal stream ${ }^{6}$. With the aim of ensuring that the experimental model adopted would be capable of causing inflammation to appear in the colon mucosa of the segments excluded from the transit, we preferred to use an inflammation grading scale that had previously been validated ${ }^{19}$. This allowed the main histological changes encountered to be considered together ${ }^{19,35}$. The results showed that in the segments excluded from the fecal stream, there was a greater degree of inflammation than in the segments with transit preserved, independent of the duration of exclusion. We found that the degree of inflammation increased with increasing duration of exclusion. These histological results assured us that the model adopted was capable of producing inflammatory changes to the colon mucosa that would allow diversion colitis to be diagnosed.

To the best of our knowledge, no studies have quantified and only one has evaluated the expression pattern of acid mucins in experimental models for diversion colitis ${ }^{6}$. In that study, modifications relating to the expression pattern of acid mucins along the colon crypts were found, by comparing segments with and without fecal stream. It was observed that in the colon with transit, sulfomucins were found in the upper two thirds of the intestinal crypts and sialomucins in the lower third. It was also observed that with increasing duration of exclusion, tissue expression of sulfomucins predominated and these were found along the whole length of the colon crypts. Regarding sialomucins, it was observed that after six weeks of exclusion, the tissue content initially increased in the deepest part of the crypts, but that sialomucins had completely disappeared by the $18^{\text {th }}$ week of exclusion. The authors suggested that this disappearance was probably related to changes in cell turnover along the crypts, which came to present a greater population of immature cells that were only capable of producing sulfomucins ${ }^{6}$.

In the present study, when we evaluated the expression pattern of each of the mucin subtypes individually, we found that the behavior in the colon with fecal stream was similar to what had previously been described ${ }^{6}$. In this colon tissue, sulfomucins predominated and were expressed in the upper two thirds of the colon crypts, while sialomucins were restricted to the lower third. This expression pattern along the colon crypts remained constant throughout the period of the experiment. In quantifying the tissue content of each of the subtypes, we found that the expression of both mucin subtypes presented small increases over the course of the experiment, thus reinforcing the importance of the SCFA supply for maintaining glycoprotein synthesis.

However, when we analyzed the colon without fecal stream, we found results differing from those previously described ${ }^{6}$. We observed that, after six weeks of fecal exclusion, there was already a significant reduction in sialomucin expression along the colon glands. This same distribution pattern was maintained after 12 and 18 weeks of fecal exclusion. In quantifying the tissue sialomucin content, we found a significant reduction in relation to the segments with fecal stream, independent of the duration of exclusion considered. The reduction in sialomucin content was related to the duration of exclusion and reached its lowest value after 18 weeks of exclusion. It is possible that the differences in sialomucin expression pattern over the first weeks of fecal exclusion were related to the experimental model used. Differing from the present study, others authors did not use any method of mechanical cleaning that would ensure complete elimination of fecal residues from the segment that was to be excluded from the fecal stream $^{6}$. The presence of fecal residues rich in SCFAs in the excluded colon might have maintained the energy supply and, furthermore, the synthesis of sialomucins in a pattern close to that of the colon with preserved transit. This could perhaps explain the increased expression of sialomucins during the first weeks that those authors found. This possibility is likely to be more common than is supposed ${ }^{31}$. In the present study, when we performed mechanical cleaning of the distal colon before the intestinal diversion, we observed that formed feces came out through the anus of all of the animals in the experimental group ${ }^{37}$. It should also be noted that Keli et al. ${ }^{6}$ evaluated the tissue content of the acid mucin subtypes subjectively, without using any technique that might have enabled quantification with greater precision. The marked reduction in sialomucins after six weeks of exclusion that we found in the present study suggests that the capacity for synthesizing this subtype of acid mucin seems to be more dependent on maintaining an adequate supply of SCFAs, or on the presence of a bacterial population capable of adequately metabolizing SCFAs.

In quantifying the tissue sulfomucin content in the colon mucosa without fecal stream, we also found a significant reduction in relation to the segment with transit preserved, independent of the duration of exclusion considered. However, we observed that the tissue sulfomucin content in the segments without fecal stream increased with increasing duration of exclusion. It is possible that this increase may be related to the presence of a greater population of cells capable of producing sulfomucins ${ }^{6}$.

It has been shown in the literature that, among the various factors capable of stimulating protein synthesis by the colon epithelium, SCFAs have a prominent position ${ }^{8}$. Studies using microarray techniques to evaluate the importance of SCFAs (in particular butyrate) in relation to the expression of 19,400 genes have demonstrated that butyrate influences the expression of 221 
genes that are specifically related to proliferation, differentiation and cell apoptosis processes ${ }^{32}$. SCFAs induce the expression of various genes that transcribe mucins, thereby increasing the expression of MUC-2 around twentyfold ${ }^{9,10,33}$. SCFAs increase cell metabolism by more than $80 \%$ and the production and secretion of mucins by the colon epithelium more than twentyfold ${ }^{8,33}$. Experimental models that inhibit the oxidation of SCFAs or that use animals that have been silenced for the MUC-2 gene are capable of causing inflammation of the colon mucosa to appear, with histological similarities to diversion colitis s $^{10,27,37,34}$. All these points reinforce the important role played by SCFAs in relation to the capacity of the colon epithelium to produce mucins and consequently to protect the mucosa against aggression coming from the intestinal lumen ${ }^{8}$. The results from the present study seem to confirm this evidence, given that we observed that the SCFA deficit that was caused by the intestinal deviation significantly decreased the total acid mucin content in tissue, mainly at the cost of sialomucins. In other words, the evidence confirms the importance of SCFAs regarding adequate production and maintenance of the first line of defense of the intestinal mucosa that is represented by the barrier of mucus that covers the colon epithelium.

The results also demonstrated that the expression pattern and production capacity of the two subtypes of acid mucin in cases of diversion colitis presented behavior that was in the inverse of what is seen among individuals with ulcerative colitis. The increasing incidence of colorectal cancer observed among individuals with ulcerative colitis in parallel with greater, more active and longer lasting inflammatory aggression suggests that other intraluminal factors may be involved in this distinct pattern of acid mucin expression. It is possible, comparing individuals with ulcerative colitis and those with diversion colitis, that the different tissue expression patterns exhibited by mucins may be related to a lower possibility of neoplastic transformation in segments that are excluded from the fecal stream because of diseases other than inflammatory intestinal diseases.

\section{Conclusion}

Changes in expression pattern and reductions in tissue acid mucin content occur in the mucosa of colon segments excluded from fecal stream, especially at the cost of sialomucins.

\section{References}

1. Glotzer DJ, Glick ME, Goldman H. Proctitis following diversion of fecal stream. Gastroenterology. 1981;80:438-41.

2. Kiely EM, Ajayi NA, Wheele RA, Malone M. Diversion procto-colitis: response to treatment with short-chain fatty acids. J Pediatr Surg. 2001;36:1514-7.

3. Giardiello, FM, Lazenby, AJ, Bayless, TM. The new colitides: collagenous, lymphocytic, and diversion colitis. Gastroenterol Clin N Am. 1995;24:717-29.

4. Biondo-Simões MLP, Greca FH, Ioshi S, Abicalaffe MD, Colnaghi MC, Mattos e Silva E, Yamasaki ES, Smaniotto G. Colite do cólon excluso: modelo experimental em ratos. Acta Cir Bras. 2000;15(Supl. 3):7-11.

5. Keli E, Bouchoucha M, Devroede G, Carnot F, Ohrant T, Cugnenc PH. Diversion-related experimental colitis in rats. Dis Colon Rectum. 1997;40:222-8.
6. Deplancke B, Gaskins HR. Microbial modulation of innate defense: goblet-cells and the intestinal mucus layer. Am J Clin Nutr. 2001;73:1131S-41S

7. Finnie IA, Dwarakanath AS, Taylor BA, Rhodes JM. Colonic mucins synthesis is increased by sodium butyrate. Gut. 1995;36:93-9.

8. Gaudier E, Rival M, Buisine M, Robineau I, Hoebler C. Butyrate enemas upregulate Muc genes expression but decrease adherent mucus thickness in mice colon. Physiol Res. 2009;59:111-9.

9. Gaudier E, Forestier L, Gouyer V, Huet G, Julien R, Hoebler C. Butyrate regulation of glycosylation-related gene expression: evidence for galectin-1 upregulation in human intestinal epithelial goblet cells. Biochem Biophys Res Commun. 2004;325:1044-51.

10. Habib NA, Dawson PN, Krausz T, Blount MA, Kersten D, Wood CB. A study of histochemical changes in mucus from patients with ulcerative colitis, Crohn's disease and diverticular disease of the colon. Dis Colon Rectum. 1986;29:15-7.

11. Agawa S, Muto T, Murioka Y. Mucin abnormality of colonic mucosa in ulcerative colitis associated with carcinoma and/or dysplasia. Dis Colon Rectum. 1988;31:387-9.

12. Allen DC, Connolly NS, Biggart JD. Mucin profiles in ulcerative colitis with dysplasia and carcinoma. Histopathology. 1988;13:413-24.

13. Castro MA, Ferreira U, Martins MH, Stoppiglia RM, Netto NR Jr. Histological and histochemical changes of the intestinal mucosa at the urothelial-enteric anastomotic site. Int Braz J Urol. 2006;32(2):222-7.

14. Shimamoto C, Hirata I, Takao Y, Takiuchi H, Morikawa H, Nakagawa Y, Katsu K. Alteration of colonic mucin after ureterosigmoidostomy. Dis Colon Rectum. 2000;43:526-31.

15. Crissey MM, Steele GD, Gittes RF. Rat model for carcinogenesis in ureterosigmoidostomy. Science. 1980;207:1079-80.

16. Martinez CAR, Waisberg J, Palma RT, Silva FZ, Cimerman G, Goffi FS. Morphometric study of gastric mucosa in dogs submitted to proximal gastric vagotomy, splenectomy or proximal gastric vagotomy associated with splenectomy. Acta Cir Bras. 2002;17:289-98.

17. Priolli DG, Margarido NF, Martinez CAR, Rotta CM, Stephani SM. Edema quantification by computerized morphometry as an evaluation parameter for the resistance of colon anastomoses. Acta Cir Bras. 2003;18:398-406.

18. Grupta RB, Harpaz N, Itzkowitz S, Hossain S, Matula S, Kornbluth A, Bodian C, Ullman T. Histologic inflammation is a risk factor for progression to colorectal neoplasia in ulcerative colitis: a cohort study. Gastroenterology. 2007;133:1099-105.

19. Swidsinski A, Loening-Bauke V, Theissig F, Engelhardt H, Bengmark S, Koch S, Lochs H, Dorfel Y. Comparative study of the intestinal mucus barrier in normal and inflamed colon. Gut. 2007;56:343-50.

20. Filipe MI. Value of histochemical reactions for mucosubstances in the diagnosis of certain pathological conditions of the colon and rectum. Gut. 1969;10:577-86.

21. Filipe MI. The value of a study of the mucosubstances in rectal biopsies from patients with carcinoma of the rectum and lower sigmoid in the diagnosis of premalignant mucosa. J Clin Pathol. 1972;25:123-8.

22. Hatayama H, Iwashita J, Kuwajima A, Abe T. The short chain fatty acid, butyrate, stimulates MUC2 mucin production in the human colon cancer cell line, LS174T. Biochem Biophys Res Commun. 2007;356:599-603.

23. Roediger WE. The starved colon: diminished mucosal nutrition, diminished absorption, and colitis. Dis Colon Rectum. 1990;33:858-62.

24. Blottiere HM, Buecher B, Galmiche JP, Chewrbut C. Molecular analysis of the effect of short-chain fatty acids on intestinal cell proliferation. Proc Nutr Soc. 2003;62:101-6.

25. Roy CC, Kien CL, Bouthillier L, Levy E. Short-chain fatty acids: ready for prime time? Nutr Clin Pract. 2006;21:351-66.

26. Brownlee IA, Knight J, Dettmar PW, Pearson JP. Action of reactive oxygen species on colonic mucus secretions. Free Radic Biol Med. 2007;43:800-8. 
27. Hamer HM, Jonkers D, Venema K, Vanhoutvin S, Troost FJ, Brummer TJ. Review article: the role of butyrate on colonic function. Aliment Pharmacol Ther. 2008;27:104-9.

28. Jørgensen JR, Clausen MR, Mortensen PB. Oxidation of short and medium chain C2-C8 fatty acids in Sprague-Dawley rat colonocytes. Gut. 1997;40:400-5.

29. Roediger WE, Nance S. Metabolic induction of experimental ulcerative colitis by inhibition of fatty acid oxidation. Br J Exp Pathol. 1986;67:773-82. 30. Corfield AP, Myerscough N, Bradfield N, Corfield Cdo A, Gough M, Clamp JR, Durdey P, Warren BF, Bartolo DC, King KR, Williams JM. Colonic mucins in ulcerative colitis: evidence for loss of sulfation. Glycoconj J. 1996;13:809-22.

31. Souza MV, Priolli DG, Portes AV, Cardinalli IA, Pereira JA, Martinez CAR. Evaluation by computerized morphometry of histopathological alterations of the colon wall in segments with and without intestinal transit in rats. Acta Cir Bras. 2008;23:417-24.
32. Daly K, Shirazi-Beechey SP. Microarray analysis of butyrate regulated genes in colonic epithelial cells. DNA Cell Biol. 2006;25:49-62. 33. Shimotoyodome A, Meguro S, Hase T, Tokimitsu I, Sakata T. Short chain fatty acids but not lactate or succinate stimulate mucus release in the rat colon. Comp Biochem Physiol A Mol Integr Physiol. 2000;125:525-31.

34 Van der Sluis M, De Koning BA, De Bruijn AC, Velcich A, Meijerink JP, Van Goudoever JB, Büller HA, Dekker J, Van Seuningen I, Renes IB, Einerhand AW. Muc2-deficient mice spontaneously develop colitis, indicating that MUC2 is critical for colonic protection. Gastroenterology. 2006;131:117-29.

\section{Correspondence:}

Carlos Augusto Real Martinez

Rua Rui Brabosa, 255/32

09190-370 Santo André - São Paulo Brazil

caomartinez@uol.com.br

Received: December 16, 2009

Review: February 10, 2010

Accepted: March 17, 2010

\section{How to cite this article}

Martinez CAR, Nonose R, Spadari APP, Máximo FR, Priolli DG, Pereira JA, Margarido NF. Quantification by computerized morphometry of tissue levels of sulfomucins and sialomucins in diversion colitis in rats. Acta Cir Bras. [serial on the Internet] 2010 May-Jun;25(3). Available from URL: http://www.scielo.br/acb 